ARTICLE

DOI: $10.1038 / \mathrm{s} 41467-017-02497-\mathrm{x}$

\title{
RAD54 N-terminal domain is a DNA sensor that couples ATP hydrolysis with branch migration of Holliday junctions
}

Nadish Goyal', Matthew J. Rossi', Olga M. Mazina', Yong Chi ${ }^{2,3}$, Robert L. Moritz ${ }^{3}$, Bruce E. Clurman ${ }^{2}$ \& Alexander $\vee$. Mazin ${ }^{1}$

In eukaryotes, RAD54 catalyzes branch migration (BM) of Holliday junctions, a basic process during DNA repair, replication, and recombination. RAD54 also stimulates RAD51 recombinase and has other activities. Here, we investigate the structural determinants for different RAD54 activities. We find that the RAD54 N-terminal domain (NTD) is responsible for initiation of BM through two coupled, but distinct steps; specific binding to Holliday junctions and RAD54 oligomerization. Furthermore, we find that the RAD54 oligomeric state can be controlled by NTD phosphorylation at S49, a CDK2 consensus site, which inhibits RAD54 oligomerization and, consequently, BM. Importantly, the effect of phosphorylation on RAD54 oligomerization is specific for BM, as it does not affect stimulation of RAD51 recombinase by RAD54. Thus, the transition of the oligomeric states provides an important control of the biological functions of RAD54 and, likely, other multifunctional proteins.

\footnotetext{
${ }^{1}$ Department of Biochemistry and Molecular Biology, Drexel University College of Medicine, Philadelphia, PA 19102, USA. ${ }^{2}$ Divisions of Clinical Research and Human Biology, Fred Hutchinson Cancer Research Center, Seattle, WA 98109, USA. ${ }^{3}$ Institute for Systems Biology, Seattle, WA 98109, USA.

Correspondence and requests for materials should be addressed to A.V.M. (email: amazin@drexelmed.edu)
} 
T he HR pathway is responsible for the repair of DNA double-strand breaks (DSBs), the most harmful types of DNA lesions, faithful chromosome segregation during meiosis, and telomerase-independent telomere maintenance ${ }^{1-3}$. HR uses homologous DNA molecules as a template to repair DSBs and therefore is, generally, an error-free process. During DSB repair by HR, the dsDNA ends undergo exonucleolytic resection to generate protruding ssDNA tails ${ }^{4}$. RAD51 recombinase binds to the ssDNA tails forming a nucleoprotein filament that performs a search for homologous dsDNA ${ }^{5}$. The RAD51ssDNA filament then invades the homologous dsDNA generating joint molecules (D-loops) that further extend into the DNA fourway cross-structure known as a Holliday Junction $(\mathrm{HJ})^{6-8}$. The $\mathrm{HJ}$ has a remarkable ability to translocate along the DNA axis through a process known as branch migration (BM), in which one strand of the DNA duplex became progressively exchanged for the homologous strand of another DNA duplex by the stepwise breakage and reformation of base pairs. In different HR mechanisms, BM may cause either dissociation or extension of joint molecules. It may also promote a restart of DNA replication stalled at a DNA damage site by switching DNA-template strands through a reversible regression of replication forks into Holliday junctions 9 .

Previously, we showed that RAD54, a member of the Rad52 epistasis group ${ }^{10,11}$, promotes $\mathrm{BM}$ of $\mathrm{H}^{9,12,13}$. BM activity of RAD54 requires ATP hydrolysis and involves the formation of higher order RAD54 oligomers on HJ-like structures ${ }^{12,14}$. RAD54 promotes $\mathrm{BM}$ with significantly greater efficiency than other known eukaryotic BM proteins, like BLM or RECQ ${ }^{13}$. Moreover, similar to RuvAB, a prototypical BM protein from E. coli, RAD54 is capable of driving $B M$ of $\mathrm{HJ}$, through large regions of DNA sequence heterology 13 .

RAD54 belongs to the SWI/SNF2 family of helicase-like proteins of Superfamily (SF) 2 helicases ${ }^{15,16}$. Similar to other known SWI/SNF proteins, but unlike canonical helicases, RAD54 does not have DNA strand-separation activity. Structurally, RAD54 is composed of the N-terminal domain (NTD) (Fig. 1), the ATPase/ DNA-binding core domain, and the C-terminal domain (CTD). The ATPase/DNA-binding core domain contains seven motifs conserved in all SF2 and SF1 proteins, which constitute the two tandem RecA-like folds responsible for protein binding to DNA and translocation in an ATPase-dependent manner ${ }^{17-19}$. The NTD (Fig. 1) and CTD are conserved among RAD54 orthologs and their functional role remains to be elucidated. The RAD54 NTD contains two CDK2 consensus motifs indicating a regulatory role of this domain (Fig. 1).

RAD54 is a multifunctional protein that, in addition to $\mathrm{BM}$, can physically interact with RAD51 $1^{20,21}$ and stimulate its DNA strand exchange activity ${ }^{22-24}$, it can also displace nucleosomes ${ }^{25-27}$ or RAD51-dsDNA complexes ${ }^{28}$. However, the structural basis for different activities of RAD54 is currently unknown.

In this study, using the N-terminal truncated RAD5496-747, we found that the NTD of RAD54 is essential for its BM activity. At the same time, the RAD54 ${ }_{96-747}$ retains the ability to translocate on dsDNA in an ATPase-dependent manner, indicating a specific role of the RAD54 NTD in BM. We found that a distinct DNAbinding site located in the NTD (Fig. 1) ${ }^{29}$ is critical for RAD54 BM. First, this site binds $\mathrm{HJ}$ and HJ-like structures with high affinity. Second, DNA binding by this site enables protein oligomerization that is required for BM. We identified a specific amino-acid residue, S49, which is important for protein oligomerization. Furthermore, we show that CDK2 phosphorylation at S49 in vitro or the S49E phosphomimetic mutation impairs DNA-dependent RAD54 oligomerization and inhibits RAD54 BM activity. Importantly, CDK2 phosphorylation has no inhibitory effect on stimulation of RAD51 recombinase by RAD54. Taking together, these data indicate that the RAD54 oligomerization is a controlled step that has a pivotal role in the regulation of the protein activities.

\begin{tabular}{|c|c|c|c|}
\hline & \multicolumn{3}{|c|}{ 12AAA14 } \\
\hline Human & 1 & MRRSLAPSQLAKRK PEGRSCDDEDWQPGI & VTARK \\
\hline Mouse & 1 & MRRSLAPSQLARRKPEDRSSDDEDWQPG & VTPK \\
\hline Chicken & 1 & ---------LAKRKAGG-EEEDGEWRPPA & $\mathrm{T}-\mathrm{QKR}$ \\
\hline Xenopus & 1 & MRRSLAPSQLAKRKQGS-SSEDEEWCEDA & $\mathrm{V}-\mathrm{PKR}$ \\
\hline Bovine & 1 & MRRSLAPSQLAKRKPEDGPSDDEDWQPGA & VTSKK \\
\hline \multirow[t]{2}{*}{ Zebrafish } & 1 & MRRSLAPSQVAKRKQGPDSDDEEDWEPDN & $\mathrm{E}-\mathrm{PQC}$ \\
\hline & & 96 & \\
\hline Human & 69 & QHEAFIRS ILSKPFKVPI PNYQGPLGSRAI & LGLK \\
\hline Mouse & 69 & QHEAFIRS ILSKPFKVPI PNYQGPLGSRAI & LGLK \\
\hline Chicken & 58 & QHEAFIRS ILSKPFKVPIPNYKGPTGLRAI & \\
\hline Xenopus & 67 & QHEAFIRS ILSKPFKIPIPNYQGGLGLRAI & LGIK \\
\hline Bovine & 70 & QHEAFIRS ILSKPFKIPIPNYQGPLGSRAI & LGLI \\
\hline Zebrafish & 63 & EHEAFIRKILSKPFKIPIPNYTGVLGLRAI & \\
\hline Human & 138 & KLPVHVVVDPILSKVLRP------------ & 155 \\
\hline Mouse & 138 & KLPVHVVVDPILSKVLRP------------ & 155 \\
\hline Chicken & 127 & KVPVHVVVDPVLSRVLRPHQREGVKFLWD & 155 \\
\hline Xenopus & 136 & KVPVHVVVDPVLGKVLRPHQ---------- & 155 \\
\hline Bovine & 139 & KLPVHVVVDPILSKVLR------------- & 155 \\
\hline Zebrafish & 132 & KLPVHVVVDPVLSKVLRPHQREGV------ & 155 \\
\hline
\end{tabular}

Fig. 1 The Rad54 NTD a.a. sequences from human (Homo sapiens), mouse (Mus musculus), chicken (Gallus gallus), xenopus (Xenopus tropicalis), bovine (Bos taurus) and zebrafish (Danio rerio) were analyzed using multiple sequence alignment program, T-coffee ${ }^{49}$. Pink, yellow, and green colored regions show high, low, and very low conservation among sequences, respectively. The red box highlights the CDK2 phosphorylation consensus sequence with arrows pointing to the residue that became phosphorylated. The blue box highlights the basic residues that were mutated to alanines with the name of the mutants indicated above the box. Residue 96 marks the first a.a. residue of the RAD54 $96-747$ truncated mutant 
a
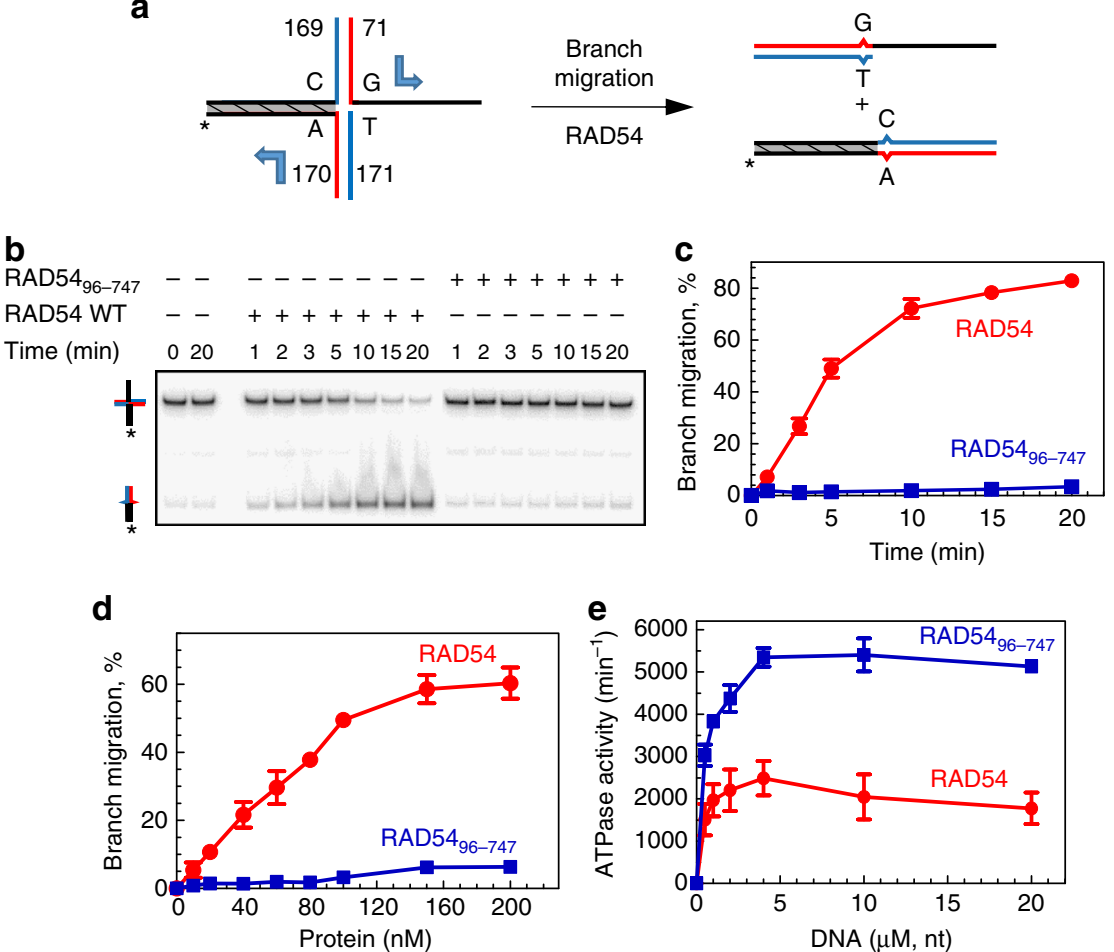

Fig. 2 The RAD54 NTD is essential for BM, but not for ATP hydrolysis. a The experimental scheme of the BM reaction. Shown is one bp heterology that was introduced into the PX junction (no. 71/169/170/171) to reduce the spontaneous BM. The shaded region denotes the heterologous DNA branch. The direction of BM is denoted by blue arrows. The asterisk indicates the ${ }^{32} \mathrm{P}$-label. The numbers correspond to oligonucleotides in Supplementary Table 1. $\mathbf{b}$ The kinetics of BM of PX junction ( $10 \mathrm{nM}$, molecules) promoted by RAD54 (30 nM) or RAD5496-747 $(30 \mathrm{nM}$ ). The BM products were analyzed by electrophoresis in $8 \%$ polyacrylamide gels. $\mathbf{c}$ Data from $\mathbf{b}$ are plotted as a graph. $\mathbf{d}$ The effect of RAD54 or RAD5496-747 concentrations on DNA BM. The reaction was carried out for $90 \mathrm{~s}$. e ATP hydrolysis by RAD54 $(20 \mathrm{nM})$ and RAD5496-747 $(20 \mathrm{nM})$ using supercoiled pUC19 as DNA substrate. Each experiment was repeated three times. Error bars represent the standard error of the mean (s.e.m.)

\section{Results}

The RAD54 NTD is essential for BM of Holliday junctions. We wished to explore the role of the NTD in the BM activity of RAD54. We constructed a truncated RAD54 $96-747$ mutant devoid of the N-terminal 95 amino-acid (a.a.) residues and tested its BM activity using ${ }^{32} \mathrm{P}$-labeled partial Holliday junctions (PX) substrate (no. 71/169/170/171) that contains three dsDNA arms and one ssDNA arm (Fig. 2a). Previously, we showed that the PX junction is a preferable substrate for RAD54 BM ${ }^{12,14}$. To reduce spontaneous $\mathrm{BM}$, a single bp of heterology was introduced in one of the four DNA arms, which during BM would create a mismatched bp in each of the two BM products (Fig. 2a). We found that the RAD54 ${ }_{96-747}$ mutant has no detectable BM activity in a range of tested protein concentrations (Fig. 2b-d; Supplementary Figure 1a). As BM activity of RAD54 depends on ATP hydrolysis $^{12}$, we tested whether the loss of BM activity by RAD54 $4_{96-747}$ is due to disruption of its ATPase activity. Surprisingly, we found that in the presence of supercoiled pUC19 DNA the RAD54 ${ }_{96-747}$ has an $2-2.5$-fold greater ATPase activity than RAD54 WT (Fig. 2e). Thus, the NTD truncation specifically disrupts the BM, but not the ATPase activity of RAD54.

RAD54 $_{96-747}$ retains DNA translocation activity. At minimum, a BM protein must translocate along the DNA axis in an ATPasedependent manner. We wanted to test whether RAD54 $96-747$ retains DNA translocation activity using a triple-helix displace-

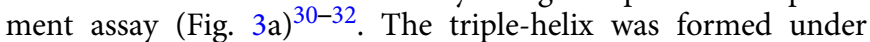
slightly acidic conditions, $\mathrm{pH} 5.5$, by annealing a pyrimidine-rich triplex-forming oligonucleotide (TFO, 22 mer) to a purine-rich sequence in pMJ5 plasmid DNA through Hoogsteen base pairing. a

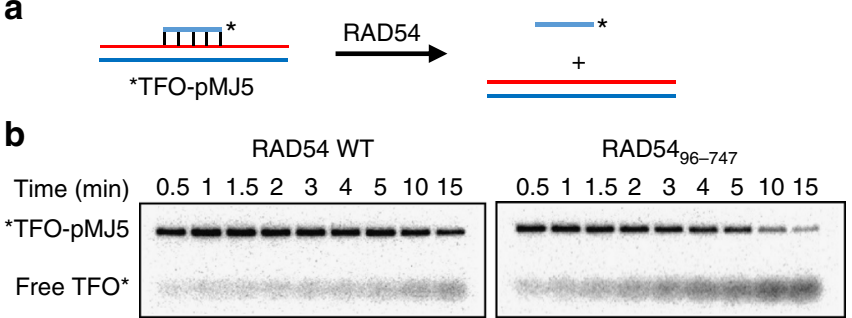

c

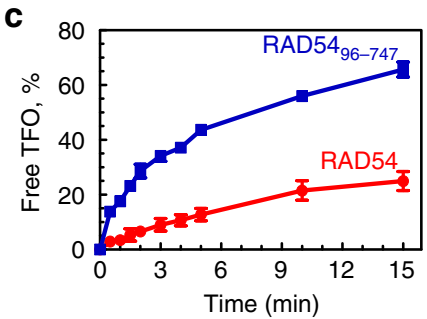

Fig. 3 The 95 a.a. $\mathrm{N}$-terminal truncation enhances DNA translocation activity of RAD54. a The experimental scheme of the triple-helix displacement assay. The triple-helix forming oligonucleotide (TFO) is paired to the linearized pMJ5 plasmid. The asterisk indicates the ${ }^{32} \mathrm{P}$-label. b The kinetics of triple-helix ( $0.5 \mathrm{nM}$, molecules) displacement by RAD54 $(5 \mathrm{nM})$ or RAD54 ${ }_{96-747}(5 \mathrm{nM})$ was analyzed by electrophoresis in $1.2 \%$ agarose gels. c Data from $\mathbf{b}$ are plotted as a graph. The values obtained in protein-free reaction (Supplementary Figure 1b) were subtracted from the values of RAD54-promoted reactions. Each experiment was repeated three times. Error bars represent the s.e.m. 
a
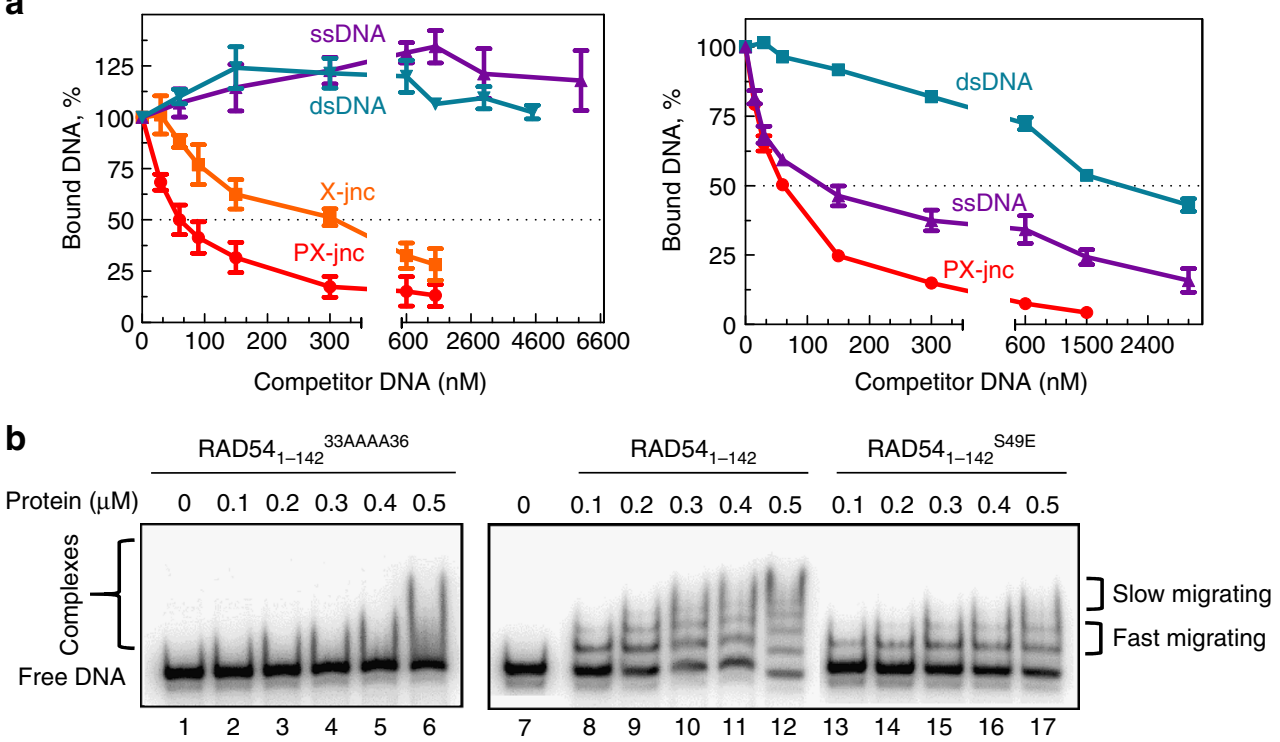

C
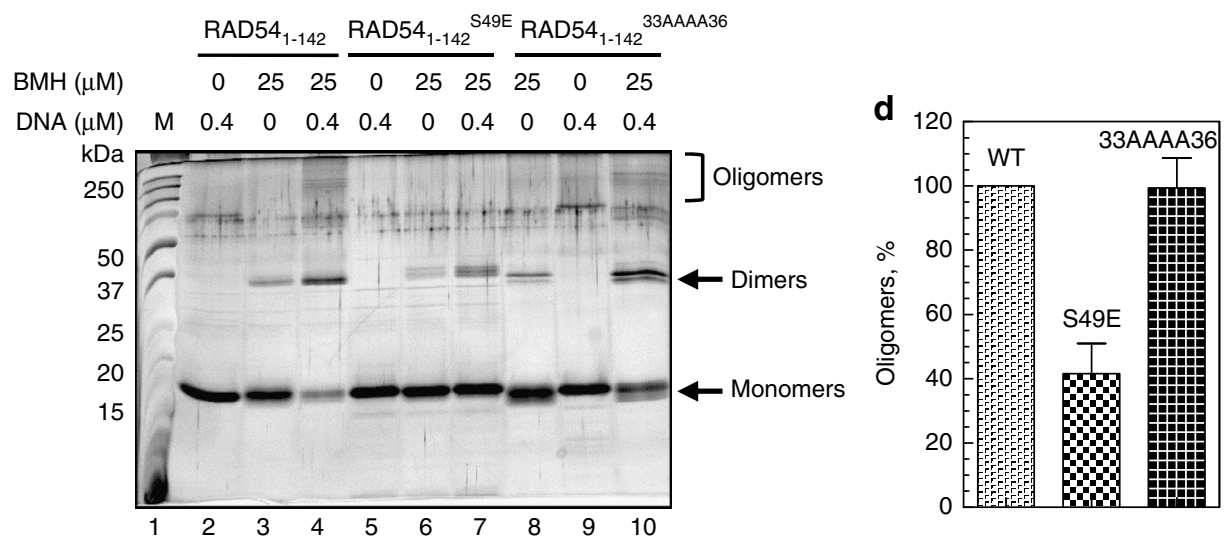

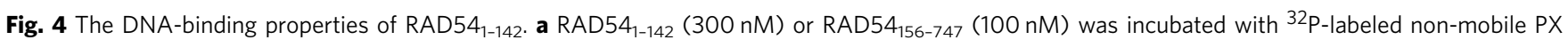
junction (no. 174/175/176/181; $30 \mathrm{nM}$ ) in the presence of the indicated concentrations of unlabeled DNA competitors. The complexes were analyzed by EMSA. $\mathbf{b}$ The effect of the S49E and 33AAAA36 mutations on RAD54 ${ }_{1-142}$ binding to PX junction (no. 174/175/176/181; $30 \mathrm{nM}$ ) was analyzed by EMSA in a $6 \%$ polyacrylamide gel. c The S49E, but not the 33AAAA36, mutation inhibits DNA-dependent oligomerization of RAD541-142. The proteins (1.2 $\mu$ M) were incubated with or without the flap DNA (no. 244/249/250; $0.4 \mu M$ ) in the presence or absence of BMH ( $25 \mu M$ ) and analyzed in a 15\% SDS-PAGE. Arrows indicate migration of the monomeric, dimeric, and oligomeric protein products. The molecular weight standards (Precision Plus; Bio-Rad) are shown. $\mathbf{d}$ The relative fractions of the oligomers in $\mathbf{c}$ were quantified and presented as a graph. Each experiment was repeated three times. Error bars represent the s.e.m.

The triple-helix is stable at neutral $\mathrm{pH}$, however once disrupted by a DNA translocating protein, it will not re-form. We found that the $\mathrm{RAD} 4_{96-747}$ retained DNA translocation activity, moreover, it was even increased, $\sim 2-2.5$-fold, relative to that of RAD54 WT (Fig. 3b, c; Supplementary Figure 1b). The increase of DNA translocation activity of RAD54 ${ }_{96-747}$ was in parallel with the increase in its ATPase activity but in a sharp contrast with the loss of the BM activity (Fig. 2).

The RAD54 NTD binds preferentially to branched DNA. In addition to the DNA-binding site in the ATPase core domain, RAD54 has a secondary DNA-binding site in the $\mathrm{NTD}^{29}$. To assess a possible role of this site in RAD54 BM of Holliday junctions, we purified two constructs, the RAD54 $4_{1-142} \mathrm{NTD}^{33}$ and

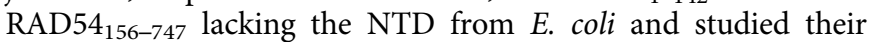
DNA-binding properties. We analyzed formation RAD54 $4_{1-142}$ complexes with ${ }^{32} \mathrm{P}$-labeled PX junction (no. 174/175/176/181) in the presence of increasing concentrations of unlabeled DNA competitors of different structures using EMSA. Similar to
RAD54 $\mathrm{WT}^{12}$, we found that RAD54 $4_{1-142}$ shows a strong binding preference for branched DNA. RAD54 $1-142$ complexes with PX junctions (no. 174/175/176/181) were stable in the presence of a 150-200-fold excess of cold ss- or dsDNA (no. 2 or no. 1/2) competitor (Fig. 4a, left panel; Supplementary Figure 2a). Also, similar to RAD54 WT, RAD54 ${ }_{1-142}$ has a strong, approximately six-fold, preference for PX junction over HJ-junction substrates. In contrast, RAD54 ${ }_{156-747}$ lost the preference for HJ-like structures; in the presence of a four-fold excess of ssDNA, $50 \%$ of the RAD54 ${ }_{156-747}$ complexes with PX junctions dissociated (Fig. 4a, right panel; Supplementary Figure $2 \mathrm{~b}$ ). These data suggest that the NTD DNA-binding site may have an important role in determining the preferential binding of RAD54 to HJ-like structures.

Mutations that impair NTD oligomerization or DNA binding. To identify the specific a.a. residues essential for DNA binding of RAD54 $1-142$, we generated three mutants: RAD54 $1-142$ 12AAA14 (KRK residues at position 12-14 mutated to alanines), 
a

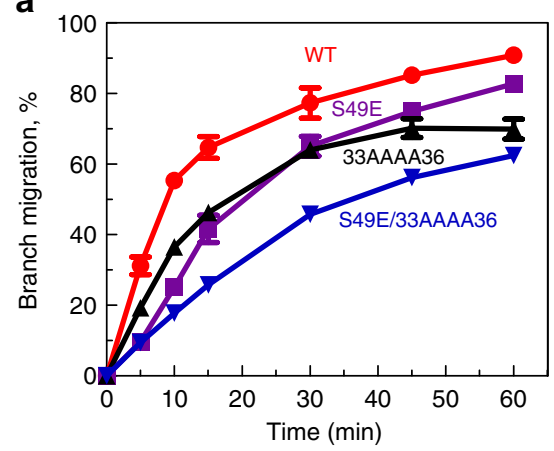

b

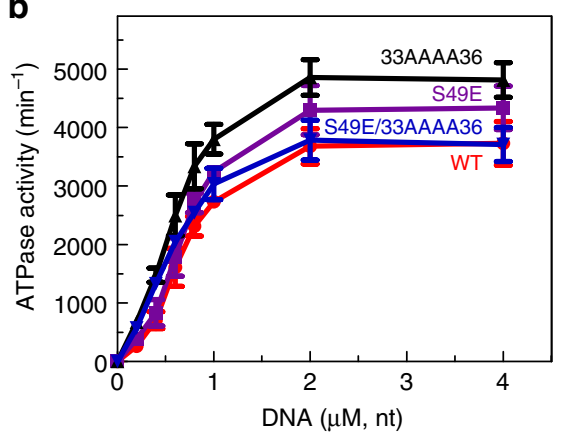

Fig. 5 The S49E and 33AAAA36 mutations inhibit BM, but not ATP hydrolysis. a The effect of the S49E and 33 AAAA36 single and double mutations on the kinetics of BM of PX junction (no. 71/169/170/171; $32 \mathrm{nM}$ ) by RAD54 $(60 \mathrm{nM})$. $\mathbf{b}$ The effect of the S49E and 33 AAAA36 mutations on ATP hydrolysis by RAD54 $(20 \mathrm{nM})$ using supercoiled pUC19 as DNA substrate. Each experiment was repeated three times. Error bars represent the s.e.m.

RAD54 $1-142$ 33AAAA36 (RKRK residues at position 33-36 mutated to alanines), and RAD54 $1-142$ A2A 53 (RK residues at position 52-53 mutated to alanines) (Fig. 1). We also constructed

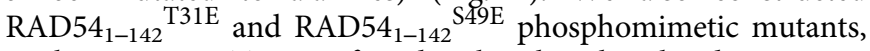
as the RAD54 NTD was found to be phosphorylated in mitotic HeLa cells on T31 and S49 ${ }^{34}$, each within a CDK consensus motif $\mathrm{X}\left(\mathrm{S} / \mathrm{T}^{\star}\right) \mathrm{PX}(\mathrm{K} / \mathrm{R})$ (Fig. 1). We wanted to test the effect of phosphorylation at these sites on DNA binding by the RAD54 NTD. All RAD54 NTD mutant proteins, except RAD54 $4_{1-142} 12$ AAA14 that failed to express under various tested growth conditions, were purified from E. coli, and examined for binding to PX junction (no. 174/175/176/181) using EMSA.

RAD54 $_{1-142} 52 \mathrm{AA53}$ bound DNA similar to the non-mutated

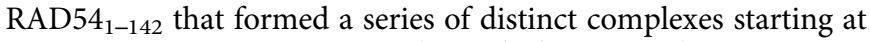
$0.1 \mu \mathrm{M}$ protein concentration (Fig. $4 \mathrm{~b}$, lanes $8-12$ ). In contrast, RAD54 $1-142$ 33AAAA36 showed only weak binding to PX junctions. No distinct complexes were observed on the gel, however, smearing observed at the highest protein concentration tested $(0.5 \mu \mathrm{M})$ likely indicated the formation of unstable DNA-protein complexes (Fig. 4b, lanes 1-6; Supplementary Figure 2d).

The S49E mutation reduced DNA binding of RAD54 $4_{1-142}$; specifically, it reduced the formation of large nucleoprotein complexes, whereas formation of small fast migrating complexes was not significantly affected (Fig. 4b, lanes 13-17; Supplementary Figure 2d). In contrast, the T31E mutation had no significant effect on DNA binding by RAD54 $4_{1-142}$ (Supplementary Figure $2 c$, d). Thus, both the 33AAAA36 and S49E mutations reduced DNA binding of RAD54 $1-142$, and the latter mutation specifically disrupted formation of large nucleoprotein complexes.

In solution, RAD54 is a monomer, but it oligomerizes in the presence of $\mathrm{DNA}^{35}$. Previously, we suggested that DNAdependent RAD54 oligomerization is necessary for $\mathrm{BM}^{14}$. To test if either of the two NTD mutations, 33AAAA36 or S49E, affect the RAD54 oligomerization, we performed cross-linking experiments using $\mathrm{BMH}$ agent that links two cysteine residues in the range of distances 3.5-15.6 $\AA^{36}$. RAD54 $1-142$, RAD54 $4_{1-142}$ S49E or RAD54 $1-142$ 33AAAA36 were incubated with the "minimal" DNA flap substrate (no. 244/249/250) containing two 15-bp dsDNA arms and one 45-nt ssDNA arm, the smallest DNA substrate that is capable to efficiently stimulate the ATPase activity of RAD54 ${ }^{14}$ followed by BMH cross-linking. The products of the protein cross-linking were analyzed on an SDSpolyacrylamide gel. Untreated RAD54 $4_{1-142}$, RAD54 $4_{1-142}$ S49E, and RAD54 $1-14233$ AAAA36 migrated in accord with the predicted size $(\sim 16 \mathrm{kDa})$ (Fig. 4c, lanes 2, 5, and 9). In the absence of DNA, $\mathrm{BMH}$ treatment gave rise to a small additional band of $\sim 36 \mathrm{kDa}$, consistent with predicted dimer size $(32 \mathrm{kDa}$ ) (Fig. 4c, lanes 3, 6, and 8 ). In the presence of DNA, BMH cross-linking resulted in a larger fraction of dimers (Fig. 4c, lanes 4, 7, and 10). For RAD5 $4_{1-142}$ and RAD54 $1-142$ 33AAA 36 , large oligomers were also observed, some of them were unable to enter the separating gel (Fig. 4c, lanes 4 and 10). Apparently, BMH cross-linking helped to visualize unstable nucleoprotein complexes formed by RAD54 $1-142$ 33AAAA36 (Fig. 4b; lanes 1-6). In contrast, higher order oligomers were nearly completely absent in RAD54 ${ }_{1-142}$ S49E (Fig. 4c, lane 7).

Thus, S49E and 33AAAA36 mutations differently affect the interaction of the RAD54 NTD with PX junctions. The S49E did not significantly disrupt the formation of fast migrating complexes in EMSA and protein dimers in cross-linking experiments, but it markedly decreased the formation of large protein oligomers (Fig. 4d). In contrast, 33AAAA36 did not affect DNA-dependent oligomerization of the RAD54 NTD, but it significantly reduced the formation of stable protein-DNA complexes visualized by EMSA (Fig. 4b).

The NTD mutations inhibit RAD54 BM. Next, we endeavored to test the effect of the 33AAAA36 and S49E mutations on the BM activity of RAD54. We constructed full-length RAD54 carrying these NTD mutations with a sumo-His tag and purified them from E. coli. In control experiments, the ATPase and BM activities of RAD54 WT with this tag purified from $E$. coli were similar to that of RAD54 purified from insect cells (Supplementary Figure 3a, b). Using PX junctions (no. 71/169/170/171) as a substrate, we found that the initial rate of $\mathrm{BM}$ for RAD54 $4^{33 A A A A 36}$ and RAD54 ${ }^{\text {S49E }}$ was reduced by $\sim 1.7$-fold and 2.5-fold, respectively. (Fig. 5a). This inhibition could not be due to a decrease in the ATPase activity that was slightly elevated in both mutants relative to RAD54 WT (Fig. 5b). Thus, the mutations that either disrupted DNA binding of the NTD or inhibited its oligomerization caused inhibition of RAD54 BM activity.

If two mutations inhibit BM by different mechanisms, one could expect that their combination would inhibit BM stronger than any of them individually. Indeed, we found that in the double mutant that the inhibition of BM activity was stronger than in either of the single mutants (Fig. 5a) consistent with the different mechanisms of inhibition caused by these mutations: DNA binding and protein oligomerization.

RAD54 NTD phosphorylation by CDK2 specifically inhibits BM. Because RAD54 oligomerization, which is required for BM, is reduced in the S49E phosphomimetic mutant, we next examined the effect of the NTD phosphorylation on the RAD54 BM activity. We first tested whether recombinant CDK2/cyclinE can phosphorylate RAD54 and the RAD54 ${ }_{1-142}$ in vitro. We observed 
that both proteins were phosphorylated with similar efficiency, consistent with the position of two CDK2 consensuses in the RAD54 NTD (Supplementary Figure 4a). When we used the RAD54 $4^{\mathrm{S} 49 \mathrm{E}}$ and RAD54 ${ }^{\mathrm{T} 31 \mathrm{E}, \mathrm{S} 49 \mathrm{E}}$ mutants as substrates for CDK2/cyclinE, the level of phosphorylation was reduced to 65 and $15 \%$ for the single and double mutant, respectively, indicating that T31 and S49 are the major phosphorylation sites in RAD54 (Supplementary Figure $4 \mathrm{~b}$ ). These data were in agreement with the results of mass spectrometry analysis, which directly demonstrated that T31 and S49 were the two main sites of RAD54 phosphorylation by CDK2 in vitro with a small contribution of other phosphorylation sites (Supplementary Figure 5a).

Next, we tested the effect of CDK2 phosphorylation on the BM activity of RAD54. We found that phosphorylation reduced RAD54 BM activity (Fig. 6a). In control with the RAD54 $499 \mathrm{~A}$ mutant, we found that the S49A mutation has no significant effect on the RAD54 BM activity (Fig. 6a). Even when the RAD54 ${ }^{\mathrm{S} 49 \mathrm{~A}}$ mutant was subjected to phosphorylation by CDK2, the RAD54 BM was not affected (Fig. 6a). These results suggest that the effect of CDK2 on RAD54 BM was specific to phosphorylation of S49 residue. In contrast, we did not observe any effect of CDK2 phosphorylation on the ATPase activity of RAD54 (Fig. 6b). We also found that CDK2 phosphorylation did not inhibit RAD54 ability to stimulate DNA strand exchange activity of RAD51 (Fig. 6c, d). These data suggest that phosphorylation of S49 in the NTD may specifically regulate RAD54 BM activity.

\section{Discussion}

RAD54 is an important HR protein that is evolutionarily conserved in eukaryotes. In vitro, it possesses several activities including stimulation of the RAD51 DNA strand exchange activity and remodeling dsDNA-protein complexes ${ }^{7}$. RAD54 stands out as the most proficient BM protein in eukaryotes known so far ${ }^{7,12,13}$. Moreover, RAD54 is the only known eukaryotic protein that is on par with E.coli RuvAB in its ability to bypass large regions of DNA heterology ( 100 bp) during BM of $\mathrm{HJ}^{13}$. This property is remarkable because, in contrast to most other BM proteins, including RuvAB or BLM, RAD54 lacks canonical DNA helicase activity.

In spite of significant structural diversity, all BM proteins show high affinity to $\mathrm{HJ}$ or $\mathrm{HJ}$-like structures and an ability to translocate on DNA in an ATPase-dependent manner. In the prototypic RuvAB complex, these two functions are segregated between RuvA and RuvB proteins, which act as the structure-specific DNA-binding protein and the ATPase motor protein, respectively $^{37,38}$. However, RAD54 and other known BM proteins including bacterial RecG and eukaryotic RecQ family helicases, BLM, RECQ1, and WRN; combine these two important activities in a single polypeptide.

Our current data demonstrate that the NTD is essential for RAD54 BM activity. The RAD54 ${ }_{96-747}$ mutant that lacks a significant portion of the NTD is almost completely devoid of BM activity, while still being proficient in DNA translocation and in ATP hydrolysis. We found that the RAD54 NTD promotes specific binding of RAD54 to $\mathrm{HJ}$ substrates. The RAD54 ${ }_{1-142}$ NTD has a preference for HJ-like DNA substrates as strong as the full-length RAD54 and removing the NTD in the RAD54 ${ }_{156-747}$ results in loss of preference for HJ-like substrates. Replacement of basic a.a. residues in the 33AAAA36 RAD54 R-142 $_{2}$ mutant by alanines diminished DNA binding by the RAD54 NTD indicating the tentative position of the NTD DNA-binding site, or at least a component of this site. Although the RAD54 NTD shows no structural homology outside of the RAD54 protein family, it may represent a functional analog of the NTD of RecG or the RecQ helicases CTD (RQC) that are responsible for specific binding to branched DNA structures ${ }^{39-41}$. Furthermore, deletion of the $95 \mathrm{a}$. a. N-terminal residues of the RAD54, similar to deletion of the BLM HRDC domain adjacent to RQC ${ }^{42}$, increased the ATPase activity of the enzyme. It is thought that HRDC may suppress the BLM ATPase activity through direct interaction with the ATPase core. Similarly, the RAD54 NTD may also interact with the ATPase core domain modulating its activity. However, this interaction may be transient, as we could not detect it in a pulldown assay.

The proteolytic cleavage analysis shows that the $S$. cerevisiae NTD Rad54 is unstructured in solution ${ }^{21}$. These data are consistent with the structural flexibility of the RAD54 NTD, which enables its interaction with various partners, like RAD51 or DNA $^{21,29,33}$. Our current data further emphasize the structural flexibility of the RAD54 NTD by demonstrating a coupling between its binding to DNA and oligomerization. Previously, we showed that RAD54 forms oligomeric structures on HJ substrates during $\mathrm{BM}^{14}$, a property that is shared with other $\mathrm{BM}$ proteins including BLM and RuvAB ${ }^{13,37}$. Our current data show that RAD54 NTD is responsible for DNA-dependent RAD54 oligomerization. Moreover, we identified NTD mutations that separately affect DNA binding and protein oligomerization. Thus, 33AAAA36 mutation decreases DNA binding of the RAD54 $1-142$ to DNA significantly. However, even this residual DNA binding appeared to be sufficient to induce protein oligomerization identified in $\mathrm{BMH}$ cross-linking experiments. In contrast, the S49E mutation only weakly inhibits initial binding of RAD54 $4_{1-142}$ to DNA but disrupts the formation of large oligomeric protein complexes visualized by $\mathrm{BMH}$ cross-linking. In full-length RAD54, each of these mutations inhibited BM and their combination increased the inhibition.

Taken together, these data suggest a two-step process during formation of the active RAD54 BM complex. First, the RAD54 NTD specifically targets RAD54 to HJ. In the presence of $\mathrm{Mg}^{2+}$ $(>100 \mu \mathrm{M}), \mathrm{HJ}$ exists in stacked conformation that is refractory to $\mathrm{BM}^{14}$. On the basis of structural data, it was recently proposed that binding of the BLM RQC domain induces structural transition of $\mathrm{HJ}$ into open conformation that is proficient in $\mathrm{BM}^{40}$. We suggest that binding of the RAD54 NTD may have a similar effect on the HJ conformation. Second, binding of the RAD54 NTD to DNA enables RAD54 oligomerization, which we show is required for $\mathrm{BM}$.

A phosphoproteomics study identified RAD54 as a target for phosphorylation at $\mathrm{S} 49^{34}$. Two CDK2 consensus sites are located in the RAD54 NTD, with putative phosphorylation sites at T31 and S49. In accord, our mass spec data identified T31 and S49 as major sites of RAD54 phosphorylation by CDK2 in vitro. Also, T31E, S49E double mutations significantly reduced CDK2 phosphorylation of RAD54. We found that S49E, but not the T31E phosphomimetic mutation, inhibits RAD54 NTD oligomerization. When incorporated into the full-length RAD54, this mutation inhibited BM activity; consistent with the important role of RAD54 oligomerization for BM. The effect of the S49E mutation is specific for BM, as it has no significant effect on stimulation of RAD51-promoted DNA strand exchange by RAD54, meaning RAD54 oligomerization is not required for stimulation of DNA strand exchange promoted by RAD51. In vitro, CDK2 phosphorylation of RAD54 also inhibited RAD54 $\mathrm{BM}$ showing an even stronger effect than the phosphomimetic S49E mutation. We suggest that CDK2 may regulate RAD54 BM activity in vivo. More work is needed to test the role of CDK2 in RAD54 regulation.

Previously, we showed that RAD54 BM activity causes dissociation of D-loops, the product of ssDNA invasion into homologous DNA-template during DSB repair ${ }^{43}$. This step of 

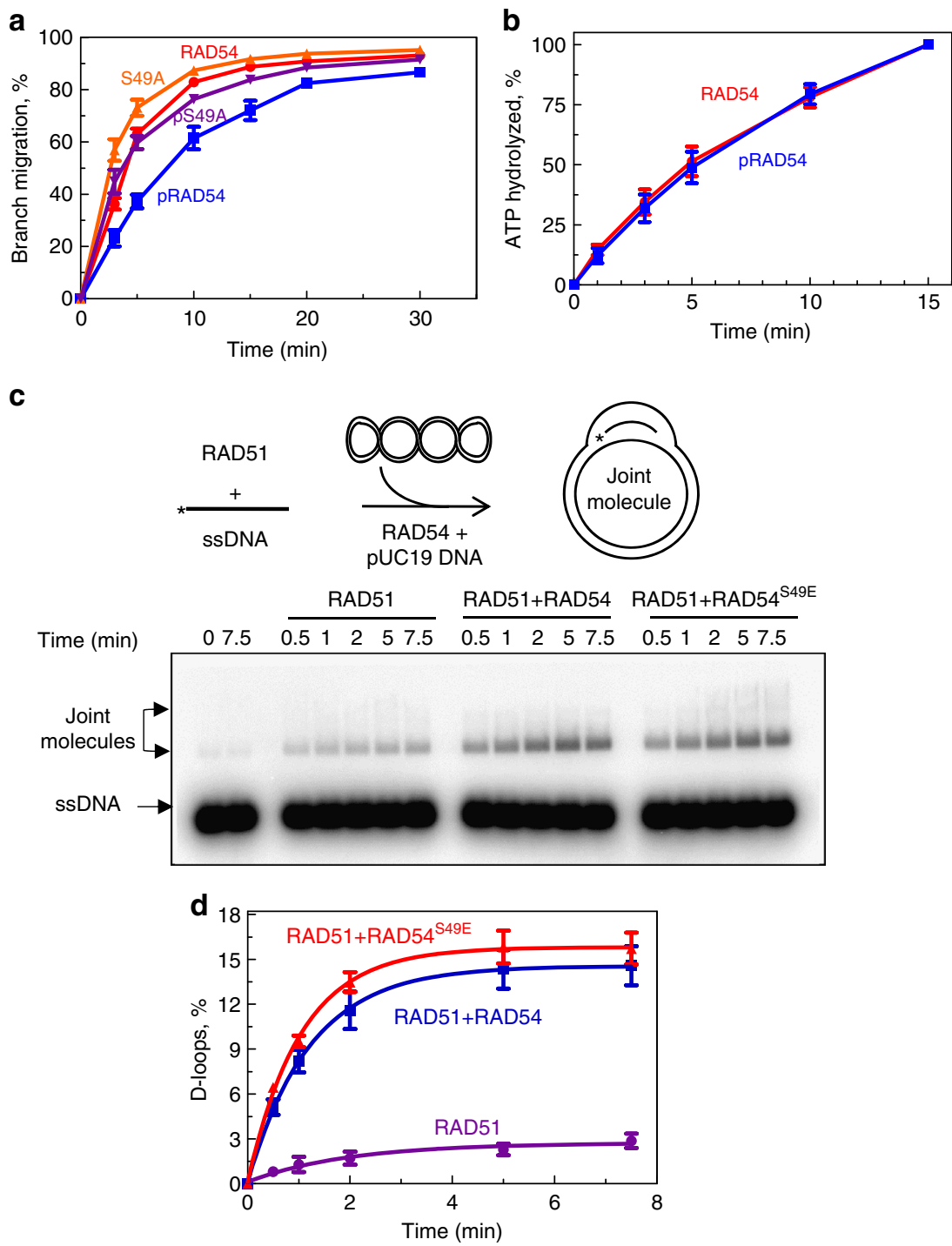

Fig. 6 Effect of CDK2 phosphorylation on the RAD54 activities. a The kinetics of BM of PX junction (no. 71/169/170/171; 10 nM) promoted by RAD54 (60 $\mathrm{nM}$ ), phosphorylated RAD54 (60 nM), RAD54 ${ }^{\mathrm{S} 49 \mathrm{~A}}(60 \mathrm{nM})$, or phosphorylated RAD54 ${ }^{\mathrm{S} 49 \mathrm{~A}}(60 \mathrm{nM})$. b The effect of RAD54 phosphorylation (60 $\mathrm{nM}$ ) on its ATPase activity was tested using supercoiled pUC19 $(2 \mu \mathrm{M}, \mathrm{nt})$ as DNA substrate. c The experimental scheme of the D-loop reaction. The nucleoprotein filaments were formed between RAD51 and ssDNA for $30 \mathrm{~min}$ at $37^{\circ} \mathrm{C}$. The reactions were then moved to $30^{\circ} \mathrm{C}$. Then RAD54 was added followed by addition of pUC19 dsDNA substrate to initiate the reaction. The effect of RAD54 (50 nM) or phosphomimetic RAD54 ${ }^{\mathrm{S} 49 \mathrm{E}}$ ( $50 \mathrm{nM}$ ) on D-loop formation by RAD51 (1.25 $\mu \mathrm{M}$ ) between ${ }^{32}$ P-labeled ssDNA (no. 90; $2.4 \mu \mathrm{M}$ nts) and pUC19 (50 $\mu \mathrm{M}$, nts). The D-loops were analyzed by electrophoresis in 1\% agarose gel. d Data from $\mathbf{c}$ are plotted as a graph. Each experiment was repeated three times. Error bars represent the s.e.m.

DSB repair, however, needs to be precisely controlled, as premature disruption of $\mathrm{D}$-loops prior to their extension by DNA polymerase may abort DSB repair. CDK2-dependent inhibition of RAD54 BM may help to delay D-loop disruption until the polymerization step is completed (Fig. 7). Recently, it was shown that Nek1 phosphorylates RAD54 at S572 in late G2 phase to modulate its interaction with RAD $51^{44}$. Thus, multiple mechanisms are in place to control different RAD54 activities in the cell.

In summary, we show that RAD54 NTD has a pivotal role in BM activity by specific binding to HJs and promoting DNAdependent oligomerization. Furthermore, the RAD54 NTD, being a target for CDK2 phosphorylation, may have a role at the hub that controls RAD54 activities in the cell.

\section{Methods}

Proteins and DNA. GST-cyclinE-CDK2 was expressed in baculovirus-infected Sf 9 cells and purified by ion-exchange and gel filtration chromatography ${ }^{45}$. All oligonucleotides used in this study (Supplementary Table 1) were purchased from
IDT Inc and purified using denaturing 6-10\% PAGE. To prepare oligonucleotide dsDNA substrates, complementary ssDNA oligonucleotides were annealed ${ }^{46}$ and stored at $-20^{\circ} \mathrm{C}$. Oligonucleotides were labeled using $\left[\gamma_{-}{ }^{32} \mathrm{P}\right] \mathrm{ATP}$ and T4 polynucleotide kinase. T4 polynucleotide kinase and restriction endonucleases were purchased from New England Biolabs. PreScission ${ }^{\mathrm{TM}}$ Protease was purchased from GE Healthcare Life Sciences.

Purification of RAD54 and RAD54 mutants from insect cells. Human RAD54 and RAD54 $4_{96-747}$ were purified from Sf21 cells ${ }^{24}$. We used RAD54 constructs with an N-terminal GST tag and a PreScission Protease ${ }^{\mathrm{TM}}$ recognition site

(LEVLFQGP). Following fractionation on a Glutathione Sepharose and a Superdex 200 column, the RAD54 pool was incubated with PreScission Protease (GE Healthcare) (10 U/100 mg of RAD54) for $4 \mathrm{~h}$ at $4{ }^{\circ} \mathrm{C}$. The sample was diluted to $100 \mathrm{mM} \mathrm{KCl}$ and loaded on a $1 \mathrm{ml}$ Resource $\mathrm{S}$ column. The fractions containing RAD54 or RAD54 mutants were analyzed for nuclease contamination, pooled, and stored in small aliquots at $-80^{\circ} \mathrm{C}$. The protein appeared nearly homogeneous in a Coomassie-stained SDS-polyacrylamide gel (Supplementary Figure 5b).

Purification of RAD54 and RAD54 mutants from E. coli. Human RAD54,

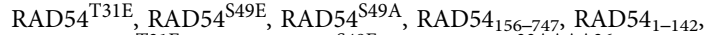
RAD54 $_{1-142}$ T31E, RAD54 ${ }_{1-142}$ S49E, RAD54 ${ }_{1-142}{ }^{33 A A A A 36}$, RAD $_{1-142} 4_{1-1}$ AA53, 


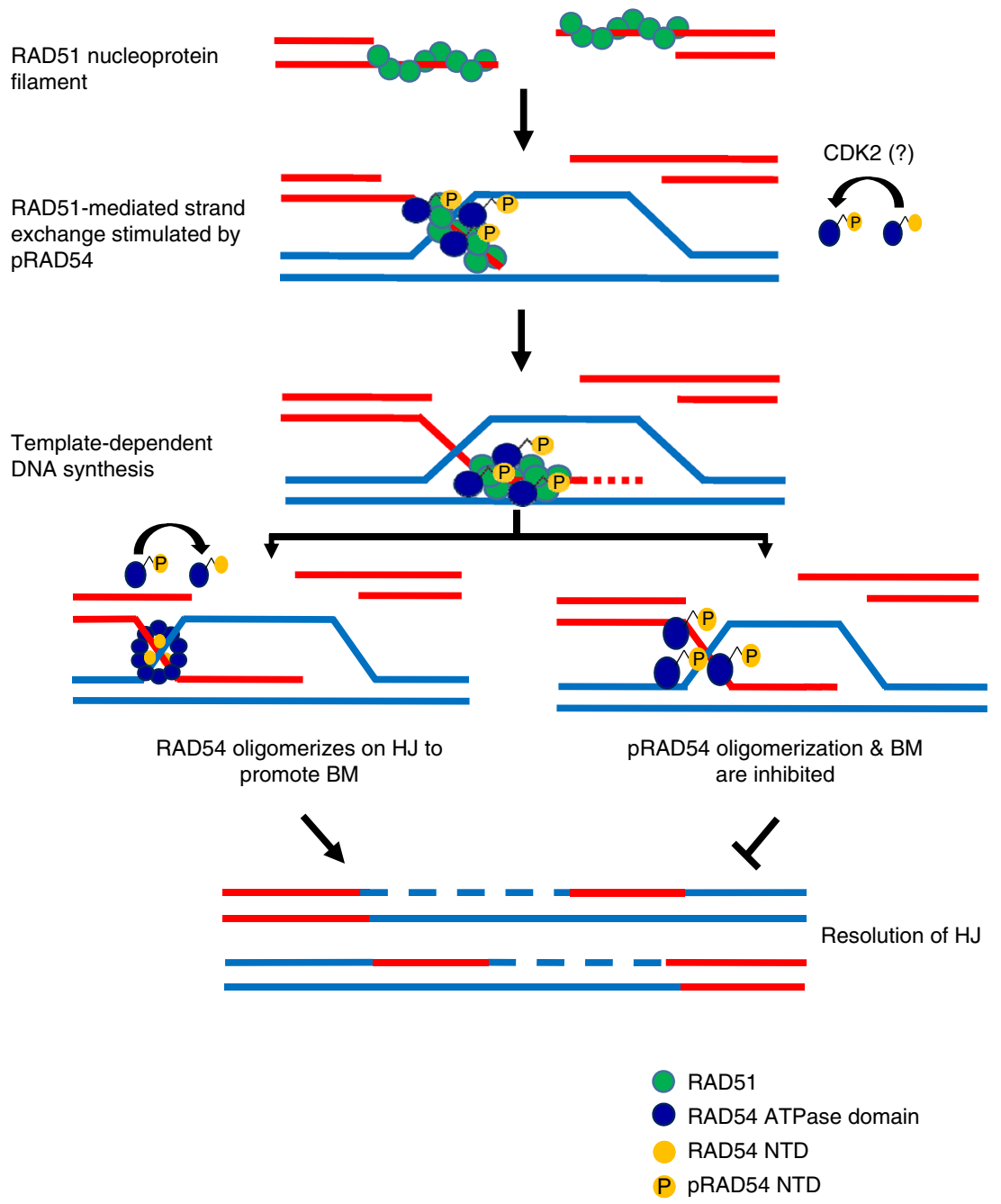

Fig. 7 Proposed mechanism of regulation of the RAD54 activities. The initial steps of HR involve exonucleolytic processing of DSB ends producing $3^{\prime}-$ ssDNA overhangs, the formation of RAD51-ssDNA nucleoprotein filaments, search for homology, and strand invasion into the homologous duplex DNAtemplate leading to the formation of joint molecules (D-loops). In its phosphorylated form, RAD54 can stimulate the strand exchange activity of RAD51. However, pRAD54 is unable to form an oligomer that is required for D-loop dissociation through BM; thus inhibiting RAD54 BM activity may provide sufficient time for the extension of the invading strand by a DNA polymerase. During later stages of HR, pRAD54 needs to be dephosphorylated so that BM could occur to complete the DSB repair process. Thus, phosphorylation modulates activities of RAD54 during HR

RAD54 33 AAAA36, and RAD54 33AAAA36, S49E with a Sumo-His affinity tag, were cloned in the pETHSUL vector ${ }^{47}$ and expressed in E. coli Rosetta 2 (DE3) cells. The cDNA sequence used for cloning was amplified using DNA primers (Supplementary Table 2) and pFastBac-HTc vector containing RAD54 cDNA as template. The cloning was performed using ligation-independent cloning protocol ${ }^{47}$. All RAD54 mutants were generated using QuickChange site directed mutagenesis kit (Agilent Technologies) and DNA primers (Supplementary Table 2). Rosetta 2 (DE3) cells were transformed with the recombinant plasmids and cultured at $37^{\circ}$ $\mathrm{C}$ to an O.D. ${ }_{600}$ of 0.4 . The cultures were transferred to $16^{\circ} \mathrm{C}$ and allowed to grow until an O.D.600 of 0.6-0.8, followed by induction of protein expression with 0.1 $\mathrm{mM}$ isopropyl-1-thio- $\beta$-D-galactopyranoside for $20 \mathrm{~h}$. Cells were harvested by centrifugation $(7000 \times g)$ and stored at $-80^{\circ} \mathrm{C}$. All purification steps were carried out at $4{ }^{\circ} \mathrm{C}$. Cells $(10 \mathrm{~g})$ were thawed and resuspended in ten volumes of lysis buffer (20 mM KH $\mathrm{PO}_{4}$ pH 7.5, $200 \mathrm{mM} \mathrm{KCl}, 10 \%$ sucrose, $10 \mathrm{mM} \mathrm{2-mercaptoethanol)}$ supplemented with EDTA-free protease inhibitor cocktail (Roche Applied Science). The cells were lysed by passing their suspension twice through an Emulsiflex C-5 (Avestin) at 15,000-20,000 psi. The crude extract was clarified by centrifugation $(135,000 \times g$ for $60 \mathrm{~min})$ and passed through $0.45 \mu \mathrm{m}$ filter. The filtrate was loaded onto a $5 \mathrm{ml} \mathrm{HiTrap} \mathrm{Ni}^{2+}$ column (GE Healthcare). The column was washed extensively with buffer A ( $20 \mathrm{mM} \mathrm{KH} \mathrm{PO}_{4} \mathrm{pH} 7.5,500 \mathrm{mM} \mathrm{KCl}, 10 \%$ glycerol, 10 $\mathrm{mM}$ 2-mercaptoethanol) supplemented with $50 \mathrm{mM}$ Imidazole. RAD54 protein was eluted using buffer A supplemented with $500 \mathrm{mM}$ imidazole and the eluate was supplemented with $2 \mathrm{mM}$ EDTA. Sumo-His tags were cleaved off by Sumo hydrolase (dtUD1) $(200 \mu \mathrm{g})$ for $4 \mathrm{~h}$ at $4{ }^{\circ} \mathrm{C}$. The cleaved RAD54 was fractionated in a Superdex 200 column $(58 \mathrm{ml})$ equilibrated with buffer A. The fractions containing RAD54 were pooled, diluted five times using buffer B $(20 \mathrm{mM}$ $\mathrm{KH}_{2} \mathrm{PO}_{4} \mathrm{pH} 7.5,10 \%$ glycerol, $10 \mathrm{mM}$ 2-mercaptoethanol) and loaded on to $1 \mathrm{ml}$ Resource $\mathrm{S}$ column (GE Healthcare), equilibrated with buffer B supplemented with $100 \mathrm{mM} \mathrm{KCl}$. The proteins were eluted with a $20 \mathrm{ml}$ gradient of $\mathrm{KC}$ $(100-450 \mathrm{mM})$ in buffer B. The fractions containing RAD54 or RAD54 mutants were analyzed for nuclease contamination, pooled, and stored in small aliquots at $-80^{\circ} \mathrm{C}$.

The RAD54 $4_{1-142}$, was purified as above except that a $58-\mathrm{ml}$ Sephacryl S-200 HR column (GE Healthcare) was used in place of Superdex 200. For the RAD54 $156-747$ the Resource S step was omitted due to large protein loses. All proteins, except RAD54 $_{156-747}$, appeared nearly homogeneous in a Coomassie-stained SDSpolyacrylamide gel (Supplementary Figure 5b). RAD54 ${ }_{156-747}$ contains some contaminating protein bands, but it was free from nuclease contamination.

Spectrophotometric ATPase assay. The hydrolysis of ATP by Rad54 protein was monitored spectrophotometrically ${ }^{48}$. The oxidation of NADH, coupled to ADP phosphorylation, resulted in a decrease in absorbance at $340 \mathrm{~nm}$, which was continuously monitored by a Hewlett-Packard 8453 diode array spectrophotometer using UV-visible ChemStation software. The rate of ATP hydrolysis was calculated from the rate of change in absorbance using the following formula: rate of $A_{340}$ decrease $\left(\mathrm{s}^{-1}\right) \times 9880=$ rate of ATP hydrolysis $\left(\mu \mathrm{M} \mathrm{min}^{-1}\right)$. The reactions were carried out in standard buffer containing $25 \mathrm{mM}$ Tris-acetate, $\mathrm{pH} 7.5,3 \mathrm{mM}$ $\mathrm{MgCl}_{2}, 1 \mathrm{mM}$ DTT, $2 \mathrm{mM}$ ATP, $3 \mathrm{mM}$ phosphoenolpyruvate, pyruvate kinase (20 
$\left.\mathrm{U} \mathrm{ml}^{-1}\right)$, lactate dehydrogenase $\left(20 \mathrm{U} \mathrm{ml}^{-1}\right)$, and NADH $\left(200 \mu \mathrm{g} \mathrm{ml}^{-1}\right)$ unless otherwise indicated, and the indicated concentrations of RAD54 and DNA. Reactions were carried out at $30^{\circ} \mathrm{C}$ unless otherwise indicated.

BM assay. PX junctions were prepared by annealing ${ }^{32} \mathrm{P}$-labeled forked DNA intermediates (\#71/169*, $32 \mathrm{nM}$ ) with $3^{\prime}$-tailed DNAs (\#170/171, $\left.48 \mathrm{nM}\right)(50 \%$ molar excess of cold tailed DNA) ${ }^{46}$. The RAD54 or the RAD54 mutant protein (60 $\mathrm{nM}$, unless indicated otherwise) was incubated with ${ }^{32} \mathrm{P}$-labeled synthetic PX junction ( $32 \mathrm{nM}$, molecules unless indicated otherwise), in a 100- $\mu$ l BM buffer containing $25 \mathrm{mM}$ Tris-acetate, $\mathrm{pH} 7.5,3 \mathrm{mM}$ magnesium acetate, $2 \mathrm{mM}$ ATP, 1 $\mathrm{mM}$ dithiothreitol, $100 \mathrm{\mu g} \mathrm{ml}^{-1} \mathrm{BSA}$, the ATP-regenerating system $\left(30 \mathrm{U} \mathrm{ml}^{-1}\right.$ creatine phosphokinase and $10 \mathrm{mM}$ creatine phosphate). The reactions were car ried out at $30^{\circ} \mathrm{C}$. Aliquots $(10 \mu \mathrm{l})$ were withdrawn at indicated time points, and DNA substrates were deproteinized by treatment with stop solution (1.36\% SDS, $1.4 \mathrm{mg} \mathrm{ml}^{-1}$ proteinase $\mathrm{K}, 6 \%$ glycerol, $0.015 \%$ bromophenol blue) for $15 \mathrm{~min}$ at 37 ${ }^{\circ} \mathrm{C}$. Samples were analyzed by electrophoresis in $8 \%$ polyacrylamide gels $(29: 1)$ in $1 \times$ TBE buffer ( $90 \mathrm{mM}$ Tris borate, $\mathrm{pH} 8.3$, and $1 \mathrm{mM}$ EDTA) at room temperature. The gels were dried on DE81 chromatography paper (Whatman) and quantified using a Storm 840 PhosphorImager (GE Healthcare).

Triple-helix displacement assay. SspI-linearized pMJ5 (100 nM, molecules) and ${ }^{32}$ P-labeled triplex-forming oligonucleotide (TFO) (oligo TFO, $22 \mathrm{mer}$ ) (100 nM, molecules) were mixed in buffer containing $25 \mathrm{mM}$ MES ( $\mathrm{pH} 5.5$ ), and $10 \mathrm{mM}$ $\mathrm{MgCl}_{2}$ and incubated for $15 \mathrm{~min}$ at $57^{\circ} \mathrm{C}$, followed by cooling to room temperature and overnight incubation. The RAD54 $(5 \mathrm{nM})$ was incubated for $5 \mathrm{~min}$ at $20^{\circ} \mathrm{C}$ in $100-\mu$ reaction buffer containing $35 \mathrm{mM}$ Tris- $\mathrm{HCl}, \mathrm{pH} 7.2,3 \mathrm{mM} \mathrm{MgCl}_{2}, 100 \mu \mathrm{g}$ $\mathrm{ml}^{-1}$ BSA, $1 \mathrm{mM}$ DTT, $2 \mathrm{mM}$ ATP, and the ATP-regenerating system $\left(30 \mathrm{U} \mathrm{ml}^{-1}\right.$ creatine phosphokinase and $15 \mathrm{mM}$ creatine phosphate). The reaction was initiated by addition of the triple-helix substrate (pMJ5 + TFO) $(0.5 \mathrm{nM}$, molecules). Overall, $10 \mu \mathrm{l}$ aliquots were withdrawn at indicated time points and the reaction was quenched by adding $5 \mu \mathrm{l}$ of stop solution containing $1.36 \% \mathrm{SDS}, 1.4 \mathrm{mg} \mathrm{ml}^{-1}$ proteinase $\mathrm{K}, 6 \%$ glycerol, $0.015 \%$ bromophenol blue followed by $15 \mathrm{~min}$ incubation at $37^{\circ} \mathrm{C}$. The DNA products were analyzed by electrophoresis in $1.2 \%$ agarose gels in buffer containing $40 \mathrm{mM}$ Tris-acetate, $\mathrm{pH} 5.5,5 \mathrm{mM}$ sodium acetate, and 1 $\mathrm{mM} \mathrm{MgCl} 2$ at $3.5 \mathrm{~V} \mathrm{~cm}^{-1}$ for $2 \mathrm{~h}$ at $4^{\circ} \mathrm{C}$. The gels were dried on DE81 chromatography paper (Whatman) and quantified using a Storm 840 PhosphorImager (GE Healthcare).

Gel retardation assay. The non-mobile ${ }^{32} \mathrm{P}$-labeled PX junction (oligos 174/175/ $176 / 181)(30 \mathrm{nM}$, molecules) was incubated in binding buffer containing $25 \mathrm{mM}$ Tris-acetate (pH 7.5), $5 \mathrm{mM}$ magnesium acetate, $100 \mu \mathrm{g} \mathrm{ml}^{-1} \mathrm{BSA}, 2 \mathrm{mM}$ DTT, 2 mM ATP, and $10 \%$ glycerol for $5 \mathrm{~min}$ at $4{ }^{\circ} \mathrm{C}$. Then RAD54 or RAD54 mutants (at indicated concentrations) were added to the reaction mixture followed by additional incubation for $45 \mathrm{~min}$. RAD54-DNA complexes were analyzed by electrophoresis in $6 \%$ non-denaturing polyacrylamide gels (29:1) in $0.25 \times$ TBE buffer (22.5 mM Tris borate $\mathrm{pH} 8.3$ and $0.5 \mathrm{mM}$ EDTA). The gels were dried on DE81 chromatography paper (Whatman) and the results were quantified using a Storm 840 PhosphorImager (GE Healthcare).

In competition-binding assay, the non-mobile ${ }^{32} \mathrm{P}$-labled PX junction (oligos $174 / 175 / 176 / 181)\left(30 \mathrm{nM}\right.$, molecules) was incubated with RAD54 $4_{1-142}(300 \mathrm{nM})$ in the presence of varying concentrations of non-radioactive DNA competitors, ssDNA (oligo 2), dsDNA (oligos 1/2), PX junction (oligos 174/175/176/181), Xjunction (oligos $174 / 175 / 176 / 177)$, in the binding buffer for $45 \mathrm{~min}$ at $4{ }^{\circ} \mathrm{C}$. The protein-DNA complexes were analyzed by electrophoresis in non-denaturing polyacrylamide gels.

In vitro CDK2 phosphorylation assay. RAD54, RAD54 ${ }_{1-142}$, or RAD54 $449 \mathrm{~A}$ (500 $\mathrm{ng}$ ) was incubated in a $10 \mu \mathrm{l}$ reaction mixture containing $5 \mathrm{mM}$ HEPES-KOH, $\mathrm{pH}$ $7.5,10 \mathrm{mM} \mathrm{MgCl}_{2}, 1 \mathrm{mM}$ DTT, $30 \mu \mathrm{M}$ ATP and $83.5 \mathrm{nM}\left[\gamma^{3}{ }^{32} \mathrm{P}\right]$ ATP $(6000 \mathrm{mCi}$ mmole $^{-1}$ ) with $500 \mathrm{ng}$ of purified CDK2/CyclinE complexes for $30 \mathrm{~min}$ at $30^{\circ} \mathrm{C}$. Following this step, the phosphorylated proteins were either used in RAD54 activity assays, or the reactions were stopped by addition of EDTA to $25 \mathrm{mM}$ and equal volume of $2 \times$ Laemmli buffer ( $100 \mathrm{mM}$ Tris- $\mathrm{HCl}$, pH 6.8, 20\% glycerol, $2 \%$ $\beta$-mercaptoethanol, $4 \%$ SDS, and $0.02 \%$ bromophenol blue) and incubation for 5 min at $75^{\circ} \mathrm{C}$ and proteins were analyzed by SDS-PAGE. The gels were stained by Blue protein stain (Denville). The gels were then dried on DE81 chromatography paper and radioactive protein bands were quantified using a Storm 840 PhosphorImager (GE Healthcare). To estimate the extent of RAD54 phosphorylation, we used radioactive standards that were prepared by diluting $\left[\gamma^{32} \mathrm{P}\right]$ ATP stock 1000,5000 and 10,000 times, and applying $1 \mu \mathrm{l}$ of each dilution onto DE81 chromatography paper that was exposed together with the gel containing phosphorylated RAD54.

D-loop formation. The nucleoprotein filaments were formed by incubating RAD51 protein with ${ }^{32} \mathrm{P}$-labeled ssDNA (\#90, 90-mer) in buffer containing $35 \mathrm{mM}$ Tris$\mathrm{HCl}, \mathrm{pH} 7.5,2 \mathrm{mM}$ ATP, $100 \mu \mathrm{g} \mathrm{ml}^{-1} \mathrm{BSA}, 1 \mathrm{mM}$ DTT, $20 \mathrm{mM} \mathrm{KCl}$ (from the protein stock), $1.5 \mathrm{mM} \mathrm{MgCl} 2,0.5 \mathrm{mM} \mathrm{CaCl}$, and the ATP-regenerating system ( $30 \mathrm{U} \mathrm{ml}^{-1}$ creatine phosphokinase and $20 \mathrm{mM}$ creatine phosphate for $30 \mathrm{~min}$ at $37^{\circ} \mathrm{C}$. The reaction was transferred to $30^{\circ} \mathrm{C}$ followed by addition of RAD54 and supercoiled pUC19 dsDNA (50 $\mu \mathrm{M}$ nucleotide or $9.3 \mathrm{nM}$ molecules) to initiate D- loop formation. Aliquots $(10 \mu \mathrm{l})$ were withdrawn at indicated time points, and Dloops were deproteinized by treatment with $5 \mu \mathrm{l}$ of stop solution (1.36\% SDS, 1.4 $\mathrm{mg} \mathrm{ml}^{-1}$ proteinase $\mathrm{K}, 6 \%$ glycerol, $0.015 \%$ bromophenol blue) for $15 \mathrm{~min}$ at $37^{\circ} \mathrm{C}$; and analyzed by electrophoresis in $1 \%$ agarose-TAE $(40 \mathrm{mM}$ Tris-acetate, $\mathrm{pH} 8.0$, and $1 \mathrm{mM}$ EDTA) gels. The gels were dried on DE81 chromatography paper and quantified using a Storm 840 PhosphorImager (GE Healthcare).

ATPase assay using thin layer chromatography (TLC). The phosphorylated or non-phosphorylated RAD54 protein $(60 \mathrm{nM})$ was incubated with supercoiled pUC19 $(2 \mu \mathrm{M}, \mathrm{nt})$ DNA substrate and $8 \mathrm{mM}$ ATP, $20 \mathrm{nCi}$ of $\left[\gamma^{-}{ }^{32} \mathrm{P}\right] \mathrm{ATP}$ in $10 \mu \mathrm{l}$ of reaction buffer containing $25 \mathrm{mM}$ Tris-acetate, $\mathrm{pH} 7.5,2 \mathrm{mM} \mathrm{DTT}, 100 \mu \mathrm{g} \mathrm{ml}^{-1}$ BSA, $11 \mathrm{mM}$ magnesium acetate at $30^{\circ} \mathrm{C}$. The level of ATP hydrolysis was determined using TLC on PEI-cellulose plates in running buffer containing $1 \mathrm{M}$ formic acid and $0.3 \mathrm{M} \mathrm{LiCl}$. The products of ATP hydrolysis were quantified using a Storm 840 PhosphorImager (GE Healthcare)

RAD54 protein cross-linking. RAD54 or RAD54 mutants $(1.2 \mu \mathrm{M})$ were incubated in $10 \mu \mathrm{l}$ reaction mixtures containing $20 \mathrm{mM}$ HEPES-KOH, $\mathrm{pH} 7.5,5 \mathrm{mM}$ $\mathrm{MgCl}_{2}, 5 \mathrm{mM}$ EDTA, and $40 \mathrm{mM} \mathrm{KCl}$ with PX junction (oligos 174/175/176/181) $\left(0.4 \mu \mathrm{M}\right.$, molecules) for $5 \mathrm{~min}$ at $25^{\circ} \mathrm{C}$. Followed by, addition of bismaleimidohexane (BMH) (Pierce) to a final concentration of $25 \mu \mathrm{M}$. After a 10min incubation at $25^{\circ} \mathrm{C}$, the reactions were quenched by the addition of $\beta$ mercaptoethanol to a final concentration of $1.1 \mathrm{M}$. The samples were analyzed by electrophoresis in $7.5 \%$ or $15 \%$ SDS-PAGE gels for RAD54 or RAD54 ${ }_{1-142}$ proteins, respectively. The proteins were visualized by silver staining (Invitrogen).

Data availability. The data that support the findings of this study are available from the corresponding author upon reasonable request.

Received: 5 June 2017 Accepted: 28 November 2017

Published online: 02 January 2018

\section{References}

1. Krejci, L., Altmannova, V., Spirek, M. \& Zhao, X. Homologous recombination and its regulation. Nucleic Acids Res. 40, 5795-5818 (2012).

2. Jasin, M. \& Rothstein, R. Repair of strand breaks by homologous recombination. Cold Spring Harb. Perspect. Biol. 5, a012740 (2013).

3. San Filippo, J., Sung, P. \& Klein, H. Mechanism of eukaryotic homologous recombination. Annu. Rev. Biochem. 77, 229-257 (2008).

4. Symington, L. S. End resection at double-strand breaks: mechanism and regulation. Cold Spring Harb. Perspect. Biol. 6, a016436 (2014).

5. Kowalczykowski, S. C. Structural biology: snapshots of DNA repair. Nature 453, 463-466 (2008)

6. Holliday, R. A mechanism for gene conversion in fungi. Genet. Res. 5, 282-304 (1964).

7. Mazin, A. V., Mazina, O. M., Bugreev, D. V. \& Rossi, M. J. Rad54, the motor of homologous recombination. DNA Repair. 9, 286-302 (2010).

8. Wyatt, H. D. \& West, S. C. Holliday junction resolvases. Cold Spring Harb. Perspect. Biol. 6, a023192 (2014).

9. Bugreev, D. V., Rossi, M. J. \& Mazin, A. V. Cooperation of RAD51 and RAD54 in regression of a model replication fork. Nucleic Acids Res. 39, 2153-2164 (2011).

10. Game, J. C. The Saccharomyces repair genes at the end of the century. Mutat. Res. 451, 277-293 (2000).

11. Krogh, B. O. \& Symington, L. S. Recombination proteins in yeast. Annu. Rev Genet. 38, 233-271 (2004).

12. Bugreev, D. V., Mazina, O. M. \& Mazin, A. V. Rad54 protein promotes branch migration of Holliday junctions. Nature 442, 590-593 (2006).

13. Mazina, O. M., Rossi, M. J., Deakyne, J. S., Huang, F. \& Mazin, A. V. Polarity and bypass of DNA heterology during branch migration of Holliday junctions by human RAD54, BLM, and RECQ1 proteins. J. Biol. Chem. 287, 11820-11832 (2012).

14. Mazina, O. M., Rossi, M. J., Thomaa, N. H. \& Mazin, A. V. Interactions of human rad54 protein with branched DNA molecules. J. Biol. Chem. 282, 21068-21080 (2007).

15. Gorbalenya, A. E. \& Koonin, E. V. Helicases: amino-acid sequence comparison and structure-function relationships. Curr. Opin. Struct. Biol. 3, 419-429 (1993).

16. Laurent, B. C., Treich, I. \& Carlson, M. The yeast SNF2/SWI2 protein has DNA-stimulated ATPase activity required for transcriptional activation. Genes Dev. 7, 583-591 (1993)

17. Caruthers, J. M. \& McKay, D. B. Helicase structure and mechanism. Curr. Opin. Struct. Biol. 12, 123-133 (2002).

18. Singleton, M. R., Dillingham, M. S. \& Wigley, D. B. Structure and mechanism of helicases and nucleic acid translocases. Annu. Rev. Biochem. 76, 23-50 (2007). 
19. Thoma, N. H. et al. Structure of the SWI2/SNF2 chromatin-remodeling domain of eukaryotic Rad54. Nat. Struct. Mol. Biol. 12, 350-356 (2005).

20. Golub, E. I., Gupta, R. C., Haaf, T., Wold, M. S. \& Radding, C. M. Interaction of human rad51 recombination protein with single-stranded DNA binding protein, RPA. Nucleic Acids Res. 26, 5388-5393 (1998).

21. Raschle, M., Van Komen, S., Chi, P., Ellenberger, T. \& Sung, P. Multiple interactions with the Rad51 recombinase govern the homologous recombination function of Rad54. J. Biol. Chem. 279, 51973-51980 (2004).

22. Petukhova, G., Stratton, S. \& Sung, P. Catalysis of homologous DNA pairing by yeast Rad51 and Rad54 proteins. Nature 393, 91-94 (1998).

23. Sigurdsson, S., Van Komen, S., Petukhova, G. \& Sung, P. Homologous DNA pairing by human recombination factors Rad51 and Rad54. J. Biol. Chem. 277, 42790-42794 (2002)

24. Mazina, O. M. \& Mazin, A. V. Human Rad54 protein stimulates DNA strand exchange activity of hRad51 protein in the presence of $\mathrm{Ca} 2+$. J. Biol. Chem. 279, 52042-52051 (2004).

25. Alexeev, A., Mazin, A. \& Kowalczykowski, S. C. Rad54 protein possesses chromatin-remodeling activity stimulated by the Rad51-ssDNA nucleoprotein filament. Nat. Struct. Biol. 10, 182-186 (2003).

26. Wolner, B. \& Peterson, C. L. ATP-dependent and ATP-independent roles for the Rad54 chromatin remodeling enzyme during recombinational repair of a DNA double strand break. J. Biol. Chem. 280, 10855-10860 (2005).

27. Alexiadis, V., Lusser, A. \& Kadonaga, J. T. A conserved N-terminal motif in Rad54 is important for chromatin remodeling and homologous strand pairing. J. Biol. Chem. 279, 27824-27829 (2004).

28. Solinger, J. A., Kiianitsa, K. \& Heyer, W. D. Rad54, a Swi2/Snf2-like recombinational repair protein, disassembles Rad51:dsDNA filaments. Mol. Cell 10, 1175-1188 (2002).

29. Wright, W. D. \& Heyer, W. D. Rad54 functions as a heteroduplex DNA pump modulated by its DNA substrates and Rad51 during D loop formation. Mol. Cell 53, 420-432 (2014)

30. Firman, K. \& Szczelkun, M. D. Measuring motion on DNA by the type I restriction endonuclease EcoR124I using triplex displacement. EMBO J. 19, 2094-2102 (2000)

31. Jaskelioff, M., Van Komen, S., Krebs, J. E., Sung, P. \& Peterson, C. L. Rad54p is a chromatin remodeling enzyme required for heteroduplex DNA joint formation with chromatin. J. Biol. Chem. 278, 9212-9218 (2003).

32. Deakyne, J. S. et al. Analysis of the activities of RAD54, a SWI2/SNF2 protein, using a specific small-molecule inhibitor. J. Biol. Chem. 288, 31567-31580 (2013).

33. Golub, E. I., Kovalenko, O. V., Gupta, R. C., Ward, D. C. \& Radding, C. M. Interaction of human recombination proteins Rad51 and Rad54. Nucleic Acids Res. 25, 4106-4110 (1997).

34. Kettenbach, A. N. et al. Quantitative phosphoproteomics identifies substrates and functional modules of Aurora and Polo-like kinase activities in mitotic cells. Sci. Signal. 4, rs5 (2011).

35. Petukhova, G., Van Komen, S., Vergano, S., Klein, H. \& Sung, P. Yeast Rad54 promotes Rad51-dependent homologous DNA pairing via ATP hydrolysisdriven change in DNA double helix conformation. J. Biol. Chem. $\mathbf{2 7 4}$ 29453-29462 (1999)

36. Green, N. S., Reisler, E. \& Houk, K. N. Quantitative evaluation of the lengths of homobifunctional protein cross-linking reagents used as molecular rulers. Protein Sci. 10, 1293-1304 (2001).

37. West, S. C. Processing of recombination intermediates by the RuvABC proteins. Annu. Rev. Genet. 31, 213-244 (1997).

38. Ariyoshi, M., Nishino, T., Iwasaki, H., Shinagawa, H. \& Morikawa, K. Crystal structure of the Holliday junction DNA in complex with a single RuvA tetramer. Proc. Natl Acad. Sci. USA 97, 8257-8262 (2000).

39. Singleton, M. R., Scaife, S. \& Wigley, D. B. Structural analysis of DNA replication fork reversal by RecG. Cell 107, 79-89 (2001).

40. Kim, S. Y., Hakoshima, T. \& Kitano, K. Structure of the RecQ C-terminal domain of human Bloom syndrome protein. Sci. Rep. 3, 3294 (2013).

41. Pike, A. C. et al. Structure of the human RECQ1 helicase reveals a putative strand-separation pin. Proc. Natl Acad. Sci. USA 106, 1039-1044 (2009).

42. Swan, M. K. et al. Structure of human Bloom's syndrome helicase in complex with ADP and duplex DNA. Acta Crystallogr. D Biol. Crystallogr. 70, 1465-1475 (2014).
43. Bugreev, D. V., Hanaoka, F. \& Mazin, A. V. Rad54 dissociates homologous recombination intermediates by branch migration. Nat. Struct. Mol. Biol. 14, 746-753 (2007).

44. Spies, J. et al. Nek1 regulates Rad54 to orchestrate homologous recombination and replication fork stability. Mol. Cell 62, 903-917 (2016).

45. Hizli, A. A. et al. Phosphorylation of eukaryotic elongation factor 2 (eEF2) by cyclin A-cyclin-dependent kinase 2 regulates its inhibition by eEF2 kinase. Mol. Cell Biol. 33, 596-604 (2013).

46. Rossi, M. J., Mazina, O. M., Bugreev, D. V. \& Mazin, A. V. Analyzing the branch migration activities of eukaryotic proteins. Methods 51, 336-346 (2010).

47. Weeks, S. D., Drinker, M. \& Loll, P. J. Ligation independent cloning vectors for expression of SUMO fusions. Protein Expr. Purif. 53, 40-50 (2007).

48. Kowalczykowski, S. C. \& Krupp, R. A. Effects of the Escherichia coli SSB protein on the single-stranded DNA-dependent ATPase activity of Escherichia coli RecA protein: evidence that SSB protein facilitates the binding of RecA protein to regions of secondary structure within single-stranded DNA. J. Mol. Biol. 193, 97-113 (1987).

49. Di Tommaso, P. et al. T-Coffee: a web server for the multiple sequence alignment of protein and RNA sequences using structural information and homology extension. Nucleic Acids Res. 39, W13-W17 (2011).

\section{Acknowledgements}

We thank Dr Patrick Loll (Drexel) for providing the pETHSUL vector and SUMO hydrolase and Dr Patrick Sung (Yale) for providing pMJ5 plasmid. We thank all members of the Mazin laboratory for assistance and feedback on this study. We acknowledge funding from the National Cancer Institute of the National Institutes of Health (NIH) grant numbers CA188347, P30CA056036 (to A.V.M.), and CA193808 (to B.E.C) for supporting this work.

\section{Author contributions}

N.G. conducted most of the experiments. M.J.R. conducted initial experiments with RAD54 NTD deletion mutants. O.M.M and N.G. carried out experiments with phosphorylated RAD54. Y.C., R.L.M. and B.E.C performed mass spec analysis of RAD54 phosphorylation. A.V.M. together with N.G., M.J.R. and O.M.M. designed experiments and analyzed data. A.V.M, O.M.M., N.G. and B.E.C. designed RAD54 phosphorylation experiments. A.V.M. and N.G. wrote the manuscript with input and suggestions from all authors.

\section{Additional information}

Supplementary Information accompanies this paper at https://doi.org/10.1038/s41467017-02497-x.

Competing interests: The authors declare no competing financial interests.

Reprints and permission information is available online at http://npg.nature.com/ reprintsandpermissions/

Publisher's note: Springer Nature remains neutral with regard to jurisdictional claims in published maps and institutional affiliations.

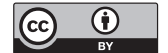

Open Access This article is licensed under a Creative Commons Attribution 4.0 International License, which permits use, sharing, adaptation, distribution and reproduction in any medium or format, as long as you give appropriate credit to the original author(s) and the source, provide a link to the Creative Commons license, and indicate if changes were made. The images or other third party material in this article are included in the article's Creative Commons license, unless indicated otherwise in a credit line to the material. If material is not included in the article's Creative Commons license and your intended use is not permitted by statutory regulation or exceeds the permitted use, you will need to obtain permission directly from the copyright holder. To view a copy of this license, visit http://creativecommons.org/ licenses/by/4.0/

(c) The Author(s) 2017 